\title{
ANALISIS FAKTOR-FAKTOR YANG MEMPENGARUHI KINERJA PEGAWAI PADA DINAS PENDAPATAN, PENGELOLAAN KEUANGAN DAN ASET (DPPKA) KOTA BENGKULU
}

\author{
Dwi Linda Yuliarti \\ Ida Anggriani \\ Program Studi Manajemen \\ Fakultas Ekonomi Universitas Dehasen Bengkulu
}

\begin{abstract}
ABSTRAK
Dwi Linda Yuliarti, Ida Anggriani; Analisis Faktor-faktor yang Mempengaruhi Kinerja Pegawai pada Dinas Pendapatan, Pengelolaan Keuangan dan Aset (DPPKA) Kota Bengkulu. Tujuan penelitian untuk mengetahui faktor yang paling dominan mempengaruhi kinerja pegawai pada DinasPendapatan, Pengelolaan Keuangan dan Aset (DPPKA) Kota Bengkulu. Metode pengumpulan data yang digunakan dalam penelitian adalah metode kuisioner, sedangkan metode analisis menggunakan skalalikert, danrating scale. Dari lima faktor yang mempengaruhi kinerja pegawai pada Dinas Pendapatan, Pengelolaan Keuangan dan Aset (DPPKA) Kota Bengkulu, empat factor yaitu personal factors, team factors, system factor, dan contextual factors mendapat persepsi dari responden dengan criteria setuju, artinya keempat factor tersebut mempengaruhi kinerja pegawai. Sedangkan satu factor yaitu leadership factors mendapat persepsi sangat setuju, artinya pemimpin sangat mempengaruhi kinerja pegawai. Faktor yang paling dominan mempengaruhi kinerja pegawai pada Dinas Pendapatan, Pengelolaan Keuangan dan Aset (DPPKA) Kota Bengkulu adalah leadership factors, karena mempunyai peranan penting dalam mengayomi, mendukung.
\end{abstract}

\section{ABSTRACT}

Dwi Linda Yuliarti, Ida Anggriani; An Analysis of Factors That Influence Employee Performance In Department of Revenue, Finance And Asset Management Of Bengkulu City. The purpose of the study to determine the most dominant factor affecting the performance of employees in Department of Revenue, Finance and Asset Management (DPPKA) Bengkulu City. Data collection method used in the study was a questionnaire method, while the method of analysis using a Likert scale, and the rating scale. By the five factors that affect the performance of employees in Department of Revenue, Finance and Asset Management (DPPKA) Bengkulu city , four factors are personal factors, team factors, systems factors, and contextual factors got the perception of respondents agreed criteria, means that four factors affect the performance of employees. While one factor got the strongly agree perception is leadership factors, that greatly affect employee performance leader. The most dominant factor affecting the performance of employees inDepartment of Revenue, Finance and Asset Management (DPPKA) Bengkulu is leadership factors, because they have an important role in nurturing, supportive.

\section{Kata kunci: Faktor-Faktor yang Mempengaruhi Kinerja Pegawai}

\section{PENDAHULUAN}

Suatu organisasi dibentuk untuk mencapai tujuan bersama, namun untuk mencapai tujuan secara efektif diperlukan manajemen yang baik dan benar. Manajemen merupakan suatu proses untuk membuat aktivitas terselenggara secara efisien dan efektif dengan dan melalui 
orang lain. Efisien menunjukkan hubungan antara input dan output dengan mencari biaya sumber daya minimum, sedangkan efektif menunjukkan makna pencapaian tujuan yang telah ditetapkan sebelumnya.

Salah satu faktor dalam organisasi yang harus mendapat perhatian pihak manajemen adalah kinerja pegawai. Kinerja (performance) merupakan hasil kerja atau prestasi kerja. Kinerja mempunyai makna lebih luas, bukan hanya menyatakan sebagai hasil kerja, tetapi juga bagaimana proses kerja berlangsung. Kinerja adalah tentang melakukan pekerjaan dan hasil yang dicapai dari pekerjaan tersebut. Kinerja adalah tentang apa yang dikerjakan dan bagaimana cara mengerjakannya. Kinerja merupakan hasil pekerjaan yang mempunyai hubungan kuat dengan tujuan strategis organisasi, kepuasaan konsumen dan memberi kontribusi ekonomi (Amstrong dan Baron dalam Wibowo, 2011:2).

Pada umumnya, kinerja pegawai diberi batasan sebagai kesuksesan seseorang dalam melaksanakan suatu pekerjaan. Lebih jelas Lawer dan Poter dalam Sutrisno (2011:150), menyatakan bahwa job performance adalah: "Successful role achievement yang diperoleh seseorang dari perbuatan-perbuatannya". Tingkat sejauh mana keberhasilan seseorang dalam melakukan tugas pekerjaannya dinamakan level of performance. Kinerja yang baik adalah kinerja yang optimal, yaitu kinerja yang sesuai standar organisasi dan mendukung tercapainya tujuan organisasi. Organisasi yang baik adalah organisasi yang berusaha meningkatkan kemampuan sumber daya manusianya, karena hal ini merupakan faktor kunci untuk meningkatkan kinerja pegawai. Oleh karena itu upaya-upaya untuk meningkatkan kinerja pegawai merupakan tantangan manajemen yang paling serius karena keberhasilan untuk mencapai tujuan dan kelangsungan hidup perusahaan tergantung pada kualitas kinerja sumber daya manusia yang ada didalamnya.

Banyak faktor yang mempengaruhi kinerja pegawai diantaranya faktor dari diri pegawai itu sendiri, kepemimpinan, kelompok atau rekan sekerja, sistem yang terbentuk dalam organisasi tersebut dan kondisi atau situasi pada saat itu. Masing-masing faktor mempunyai pengaruh tersendiri pada masing-masing pegawai, dan dalam setiap organisasi masing-masing faktor tersebut mempunyai pengaruh yang berbeda, karena tergantung keadaan organisasi tersebut. Peningkatan kinerja pegawai tidak terlepas dari setiap pegawai, untuk melaksanakan tugas dan fungsinya sebagai abdi negara dalam mencapai tujuan organisasi atau instansi sesuai visi dan misi yang telah ditetapkan.

Dinas Pendapatan, Pengelolaan Keuangan dan Aset (DPPKA) Kota Bengkulu merupakan salah satu SKPD di lingkungan Pemerintah Daerah Kota Bengkulu yang mengelola dan menggali sumber pendapatan asli daerah kota Bengkulu. Dalam menjalankan aktivitasnya Dinas Pendapatan, Pengelolaan Keuangan dan Aset (DPPKA) Kota Bengkulu lebih berhubungan langsung dengan masyarakat. Sebagai Pegawai Negeri Sipil yang mempunyai tugas pokok memberikan pelayanan prima kepada masyarakat, maka dituntut mampu melaksanakan tugas dan fungsinya dengan baik sesuai dengan aturan yang berlaku.

\section{TINJAUAN LITERATUR Kinerja Pegawai}

Kinerja merupakan hasil kerja yang mempunyai hubungan kuat dengan tujuan strategis organisasi, kepuasan konsumen, dan memberi kontribusi pada ekonomi. Dengan demikian kinerja adalah tentang melakukan pekerjaan dan hasil yang dicapai dari pekerjaan tersebut. Kinerja adalah tentang apa yang dikerjakan dan bagaimana mengerjakannya (Wibowo, 2011:7).

Secara etimologi, kinerja berasal dari kata prestasi kerja (performance). Kinerja adalah merupakan perilaku yang nyata yang ditampilkan setiap orang sebagai prestasi kerja yang dihasilkan oleh karyawan sesuai dengan perannya dalam perusahaan (Rivai, 2004:309). Hasibuan, 2001:34 menyatakan bahwa kinerja (prestasi kerja) adalah suatu hasil kerja yang dicapai seseorang dalam melaksanakan tugas-tugas yang dibebankan kepadanya yang didasarkan atas kecakapan, pengalaman dan kesungguhan serta waktu. sedangkan kinerja menurut Mangkunegara (2006:67) adalah: "Hasil kerja secara kualitas dan kuantitas yang 
dicapai oleh seorang pegawai dalam melaksanakan tugasnya sesuai dengan tanggung jawab yang diberikan padanya".

Lebih jelas Sutrisno (2011:151), bahwa kinerja atau prestasi kerja adalah: "Sebagai hasil yang telah dicapai seseorang dari tingkah laku kerjanya dalam melaksanakan aktivitas kerja. Informasi tentang tinggi rendahnya prestasi kerja seorang karyawan tidak dapat diperoleh begitu saja, tetapi diperoleh melalui proses yang panjang, yaitu proses penilaian prestasi kerja karyawan yang disebut istilah performance appraisal".

Agar setiap pegawai memiliki kinerja yang baik, maka perlu diminij dengan baik. Seperti yang dijelaskan oleh Wibowo (2011:7), bahwa manajemen kinerja adalah manajemen tentang menciptakan hubungan dan memastikan komunikasi yang efektif. Manajemen kinerja memfokuskan tentang apa yang diperlukan oleh organisasi, manajer, dan pekerja untuk berhasil. Manajemen kinerja dikelola untuk memperoleh sukses. Pengertian lain dijelaskan oleh Bacal dalam Wibowo (2011:8), manajemen kinerja adalah: "Proses komunikasi yang dilakukan secara terus menerus dalam kemitraan antara karyawan dengan atasan langsungnya. Proses komunikasi ini meliputi kegiatan membangun harapan yang jelas serta pemahaman mengenai pekerjaan yang yang akan dilakukan. Proses komunikasi merupakan suatu sistem, memiliki sejumlah bagian yang semuanya harus diikut sertakan, apabila manajemen kinerja ini hendak memberikan nilai tambah bagi organisasi, manajer dan karyawan.

Performance diterjemahkan menjadi kinerja, juga berarti prestasi kerja, pelaksanaan kerja, pencapaian kerja, dan hasil kerja/unjuk kerja/penampilan kerja (LAN, dalam Sedarmayanti, 2005:50). Kinerja mempunyai hubungan erat dengan masalah produktivitas karena merupakan indikator dalam menentukan bagaimana usaha untuk mencapai produktivitas yang tinggi dalam suatu organisasi. Sehubungan dengan hal tersebut maka upaya untuk mengadakan penilaian terhadap kinerja di suatu organisasi merupakan hal yang penting.

Produktivitas menurut Soeprihanto dalam Triton (2010:80), adalah: "Perbandingan antara hasil-hasil yang dicapai dengan keseluruhan sumber daya yang dipergunakan atau perbandingan jumlah produksi (output) dengan sumber daya yang dipergunakan (input)".

Schuller (2003:11) menjelaskan kriteria kinerja karyawan dilihat dari:

a. Prestasi kerja artinya hasil yang dicapai seseorang dalam melaksanakan tugas-tugasnya yang didasarkan atas kecakapan, usaha dan kesempatan.

b. Produktivitas maksudnya adalah perbandingan antara hasil yang dicapai (output) dengan keseluruhan sumber daya yang digunakan (input)

c. Pengetahuan atau wawasan berarti upaya untuk mermperbaiki dan meningkatkan wawasan, kemampuan sikap dan sifat-sifat kepribadian dan kemampuan.

Berdasarkan tinggi rendahnya kinerja, Fuad (2000:62) mengklasifikasikan kinerja karyawan dapat menjadi tiga, yaitu: 1) Kinerja tinggi (hight performer) yaitu bawahan yang karena oleh upayanya sendiri senantiasa dapat melampaui tolok ukur kinerja yang telah ditetapkan baginya oleh manjemen, walaupun dalam kondisi yang sulit sekalipun; 2) Kinerja sedang (statisfactory) yaitu bawahan yang dapat mencapai kinerja yang diharapkan apabila kondisi yang dihadapi normal, atau gagal mencapai tingkat kinerja yang ditetapkan karena faktor eksternal di luar jangkauan bawahan tersebut; 3) Kinerja rendah (low performer) yaitu; bawahan yang dikarenakan oleh usahanya sendiri, yang senantiasa tidak pernah berhasil dalam mencapai standar kerja diinginkan bagi organisasi.

Maier yang dikutip oleh As'ad (2002:47) yang mengatakan bahwa biasanya orang yang tingkat kinerjanya tinggi disebut sebagai orang produktif dan sebaliknya orang yang kinerjanya tidak mencapai standar, dikatakan sebagai orang yang tidak produktif.

Dari uraian di atas dapat disimpulkan bahwa kinerja merupakan hasil kerja baik hasil kerja pegawai secara individu maupun hasil kerja organisasi atau instansi secara keseluruhan. Sedangkan manajemen kinerja adalah merupakan gaya manajemen dalam mengelola sumber daya yang berorientasi pada kinerja yang melakukan proses komunikasi secara terbuka dan berkelanjutan dengan menciptakan visi bersama dan pendekatan strategis serta terpadu sebagai kekuatan pendorong untuk mencapai tujuan organisasi. 


\section{Pengukuran Kinerja Pegawai}

Pengukuran kinerja pelayanan publik sering kali dipertukarkan dengan pengukuran kinerja pemerintah. Hal ini tidaklah terlalu mengherankan karena pada dasarnya pelayanan publik memang menjadi tanggung jawab pemerintah. Dengan demikian, ukuran kinerja pemerintah dapat dilihat dari kinerjanya dalam menyelenggarakan pelayanan publik. Demikian juga dengan organisasi swasta, kinerja pelayanan organisasi swasta sering dilihat sebagai kinerja organisasi tersebut karena memang organisasi tersebut menjalankan pelayanan. Sehingga apabila organisasi tersebut menyelenggarakan pelayanan dengan baik, maka kinerja organisasi tersebut dapat dianggap baik. Dengan demikian kinerja organisasi dan kinerja pelayanan sesuatu organisasi ibarat dua sisi dari satu mata uang yang sama (Ratminto dan Winarsih, 2007:173).

Hasibuan (2001:128) menyebutkan bahwa kinerja merupakan representasi dari sikap mental pegawai yang ingin bekerja keras yang perwujudannya dapat dilihat dari:

a. Berkaitan dengan diri sendiri, dapat dilihat dari peningkatan: a) pengetahuan bidang pekerjaan, b) keterampilan kerja, c) disiplin kerja, d) upaya probadi dalam meningkatkan kualitas kerja, e) ketekunan dalam bekerja.

b. Berkaitan dengan pekerjaan, dapat dilihat dari: a) manajemen dan metode kerja yang lebih baik, b) penghematan biaya, c) ketepatan waktu dalam bekerja, d) sistem dan penguasaan teknologi yang lebih baik.

Tyson dan Jackson (2001:76), menjelaskan bahwa meningkatkan kinerja merupakan konsep sederhana tetapi penting yang didasarkan pada ide bahwa mengukur kinerja meningkat dengan cepat dan terus menerus dengan cara meninjau keberhasilan dan kegagalannya. Setelah setiap tugas diselesaikan kinerjanya harus ditinjau, dan atas tinjauan tersebut akan dapat dibuat sekumpulan aturan yang kuat untuk kinerja yang tinggi.

Kinerja yang telah diberikan oleh pegawai berupa prestasi kerja perlu mendapat perhatian dari pimpinan atau dengan kata lain perlu mendapat penilaian. Fhatoni (2006:124), menjelaskan penilaian prestasi kerja adalah: "Upaya membandingkan prestasi aktual pegawai dengan prestasi kerja yang diharapkan darinya. Untuk menentukan apakah suatu pekerjaan bisa dikerjakan/diselesaikan dengan baik, maka uraian pekerjaan akan sangat membantu dalam penentuan sasaran pekerjaan". Sedangkan Handoko (2008:135), penilaian prestasi kerja (performance appraisal), adalah: "Proses melalui mana organisasi-organisasi mengevaluasi atau menilai prestasi kerja karyawan. Kegiatan ini dapat memperbaiki keputusan-keputusan personalia dan memberi umpan balik kepada para karyawan tentang pelaksanaan kerja mereka". Kegunaan-kegunaan penilaian prestasi kerja dapat dirinci, sebagai berikut:

a. Perbaikan prestasi kerja

Umpan balik pelaksanaan kerja memungkinkan karyawan, manajer dan departemen personalia dapat membetulkan kegiatan-kegiatan mereka untuk memperbaiki prestasi.

b. Penyesuaian-penyesuaian kompensasi.

Evaluasi prestasi kerja membantu para pengambil keputusan dalam menentukan kenaikan upah, pemberian bonus dan bentuk kompensasi lain.

c. Keputusan-keputusan penempatan.

Promosi, transfer dan demosi biasanya didasarkan pada prestasi kerja masa lalu atau antisipasinya. Promosi sering merupakan bentuk penghargaan terhadap prestasi kerja masa lalu.

d. Kebutuhan-kebutuhan latihan dan pengembangan.

Prestasi kerja yang jelek mungkin menunjukkan kebutuhan latihan. Demikian juga, prestasi yang baik mungkin mencerminkan potensi yang harus dikembangkan.

e. Perencanaan dan pengembangan karier.

Umpan balik prestasi mengarahkan keputusan-keputusan karier, yaitu tentang jalur karier tertentu yang harus diteliti.

f. Ketidakakuratan informasional.

Prestasi kerja yang jelek mungkin menunjukkan kesalahan-kesalahan dalam informasi analisis jabatan, rencana-rencana sumber daya manusia, atau komponen-komponen lain 
sistem informasi manajemen personalia. Menggantungkan diri pada informasi yang tidak akurat dapat menyebabkan keputusan-keputusan personalia diambil tidak tepat.

g. Kesalahan-kesalahan desain pekerjaan.

Prestasi kerja yang jelek mungkin merupakan suatu tanda kesalahan dalam desain pekerjaan. Penilaian prestasi membantu diagnosa kesalahan-kesalahan tersebut.

h. Kesempatan kerja yang adil.

Penilaian prestasi kerja secara akurat akan menjamin keputusan-keputusan penempatan internal diambil tanpa diskriminasi.

i. Tantangan-tantangan eksternal.

Kadang-kadang prestasi kerja dipengaruhi oleh faktor-faktor di luar lingkungan kerja, seperti keluarga, kesehatan, kondisi finansial, atau masalah-masalah pribadi lainnya. Dengan penilaian prestasi departemen personalia mungkin dapat menawarkan bantuan.

Pengukuran kinerja pegawai dapat dilakukan dengan menggunakan instrumen pengukuran kinerja yang dikembangkan oleh Zeithaml, Parasuraman dan Berry (dalam Ratminto dan Winarsih, 2007:182), sebagai berikut:

a. Ketampakan fisik (tangible).

b. Reliabilitas (reability).

c. Responsivitas (responsiveness).

d. Kompetensi (competence).

e. Kesopanan (courtesy).

f. Kreadibilitas (credibility).

g. Keamanan (security).

h. Akses (access).

i. Komunikasi (communication).

j. Pengertian (understanding the customer).

Pengukuran kinerja pegawai bertujuan untuk menilai prestasi kerja setiap pegawai.

Menurut Handoko (2008:135), kegunaan-kegunaan penilaian prestasi kerja antara lain sebagai berikut :

a. Perbaikan prestasi kerja.

Umpan balik pelaksanaan kerja memungkinkan karyawan, manajer dan departemen personalia dapat membetulkan kegiatan-kegiatan mereka untuk memperbaiki prestasi.

b. Penyesuaian-penyesuaian kompensasi

Evaluasi prestasi kerja membantu para pengambil keputusan dalam menentukan kenaikan upah, pemberian bonus dan bentuk kompensasi lainnya.

c. Keputusan-keputusan penempatan.

Promosi, transfer dan demosi biasanya didasarkan pada prestasi kerja masa lalu atau antisipasinya. Promosi sering merupakan bentuk penghargaan terhadap prestasi kerja masa lalu.

d. Kebutuhan-kebutuhan latihan dan pengembangan.

Prestasi kerja yang jelek mungkin menunjukan kebutuhan latihan. Demikian juga prestasi yang baik mungkin mencerminkan potensi yang harus dikembangkan.

e. Perencanaan dan pengembangan karier.

Umpan balik prestasi mengarahkan keputusan-keputusan karier, yaitu tentang jalur karier tertentu yang harus diteliti.

f. Penyimpangan-penyimpangan proses staffing

Prestasi kerja yang baik atau jelek mencerminkan kekuatan atau kelemahan prosedur staffing departemen personalia.

g. Ketidak akuratan informasional

Prestasi kerja yang jelek mungkin menunjukan kesalahan-kesalahan dalam informasi analisis jabatan, rencana-rencana sumberdaya manusia, atau komponen-komponen lain sistem informasi manajemen personalia. Mengantungkan diri pada informasi yang tidak akurat dapat menyebabkan keputusan-keputusan personalia yang diambil tidak tepat.

h. Kesalahan-kesalahan desain pekerja. 
Prestasi kerja yang jelek mungkin merupakan suatu tanda kesalahan dalam desain pekerjaan. Penilaian prestasi membantu diagnosa kesalahan-kesalahan tersebut.

i. Kesempatan kerja yang adil

Penilaian prestasi kerja secara akurat akan menjamin keputusan-keputusan penempatan internal diambil tanpa diskriminasi.

j. Tantangan-tantangan eksternal.

Kadang-kadang prestasi kerja dipengaruhi oleh faktor-faktor di luar lingkungan kerja seperti keluarga, kesehatan, kondisi finansial atau masalah-masalah pribadi lainnya. Dengan penilaian prestasi departemen personalia mungkin data menawarkan bantuan.

\section{Faktor-Faktor yang Mempengaruhi Kinerja}

Proses kinerja organisasional dipengaruhi oleh banyak faktor. Hersey, Blanchard, dan Johnson menggambarkan hubungan antara kinerja dengan faktor-faktor yang mempengaruhi dalam bentuk satelite model. Menurut satelite model, kinerja organisasi diperoleh terjadinya integrasi dan faktor-faktor pengetahuan, sumber daya bukan manusia, posisi strategis, proses sumber daya manusia dan struktur. Kinerja dilihat sebagai pencapaian tujuan dan tanggung jawab bisnis dan sosial dari persepektif pihak yang mempertimbangkan (Wibowo, 2011:98).

Pendapat lain tentang faktor-faktor yang mempengaruhi kinerja, antara lain dikemukakan Amstrong dan Baron dalam Wibowo (2011:100), sebagai berikut:

a. Personal factors, ditunjukkan oleh tingkat keterampilan, kompetensi yang dimiliki, motivasi dan komitmen individu.

b. Leadership factors, ditentukan oleh kualitas dorongan, bimbingan, dan dukungan yang dilakukan manajer dan team leader.

c. Team factors, ditunjukkan oleh kualitas dukungan yang diberikan oleh rekan sekerja.

d. System factors, ditunjukkan oleh adanya sistem kerja dan fasilitas yang diberikan organisasi.

e. Contextual/situational factors, ditunjukkan oleh tingginya tingkat tekanan dan perubahan lingkungan internal dan eksternal.

Sementara itu, Poter dan Lawler berpendapat bahwa kinerja merupakan fungsi dari keinginan melakukan pekerjaan, keterampilan yang perlu untuk menyelesaikan tugas, pemahaman yang jelas atas apa yang dikerjakan dan bagaimana mengerjakannya. Dengan demikian, dapat dirumuskan model persamaan kinerja = $\mathrm{f}$ (keinginan melakukan pekerjaan, keterampilan, pemahaman apa dan bagaimana melakukan). Sementara itu, Lorsch dan Laurence menggunakan pemahaman bahwa kinerja adalah fungsi atribut individu, organisasi, dan lingkungan sehingga dirumuskan model persamaan kinerja $=\mathrm{f}$ (atribut individu, organisasi, lingkungan).

\section{Kerangka Analisis}

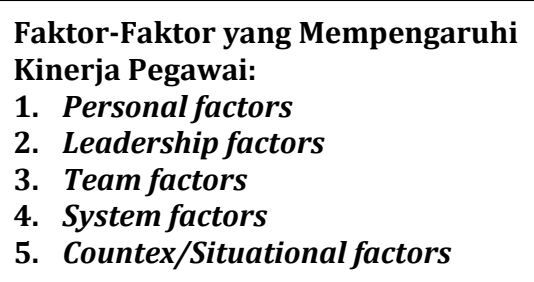

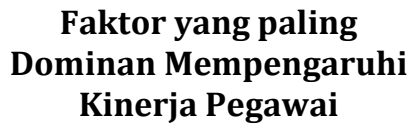




\section{HASIL PENELITIAN DAN PEMBAHASAN Karakteristik Responden}

Dari hasil kuisioner diperoleh informasi tentang karakterisitik 50 orang responden yang merupakan sampel dalam penelitian ini. Adapun karakteristik responden tersebut sebagai berikut:

a. Karakteristik responden berdasarkan jenis kelamin.

Tabel 1. Karakteristik Responden Berdasarkan Jenis Kelamin

\begin{tabular}{|c|c|c|}
\hline Jenis Kelamin & $\begin{array}{c}\text { Frekuensi } \\
\text { (orang) }\end{array}$ & Persentase (\%) \\
\hline Laki-Laki & 21 & 42,00 \\
\hline Perempuan & 29 & 58,00 \\
\hline Jumlah & 50 & 100,00 \\
\hline
\end{tabular}

Sumber: Data Penelitian, 2013

Dari tabel 1 di atas diketahui 29 orang atau 58\% sampel dalam penelitian ini adalah perempuan, dan 21 orang atau $42 \%$ berjenis kelamin laki-laki. Pemilihan responden lebih banyak berjenis kelamin perempuan ini dengan pertimbangan bahwa jumlah Pegawai Negeri Sipil di lingkungan Dinas Pendapatan, Pengelolaan Keuangan dan Aset (DPPKA) Kota Bengkulu lebih banyak berjenis kelamin perempuan.

b. Karakteristik responden berdasarkan pendidikan.

Tabel 2. Karakteristik Responden Berdasarkan Pendidikan

\begin{tabular}{|l|c|c|}
\hline \multicolumn{1}{|c|}{ Tingkat Pendidikan } & Frekuensi (orang) & Persentase (\%) \\
\hline SMA & 14 & 28,00 \\
\hline Diploma & 6 & 12,00 \\
\hline S1 & 28 & 56,00 \\
\hline S2 & 2 & 4,00 \\
\hline Jumlah & $\mathbf{5 0}$ & $\mathbf{1 0 0 , 0 0}$ \\
\hline
\end{tabular}

Sumber: Data Penelitian, 2013

Tabel 2 di atas menunjukkan bahwa mayoritas pendidikan responden adalah S1 yaitu 28 orang atau 56,00\% dari jumlah sampel. Pemilihan responden lebih banyak berpendidikan S1, karena tingkat pendidikan Pegawai Negeri Sipil khususnya pada Dinas Pendapatan, Pengelolaan Keuangan dan Aset (DPPKA) Kota Bengkulu pada saat ini adalah S1. Hal ini sesuai dengan tingkat kebutuhan pegawai sekarang minimal S1.

c. Karakteristik responden berdasarkan golongan.

Tabel 3. Karakteristik Responden Berdasarkan Golongan

\begin{tabular}{|l|c|c|}
\multicolumn{1}{|c}{ Golongan } & $\begin{array}{c}\text { Frekuensi } \\
\text { (orang) }\end{array}$ & Persentase (\%) \\
\hline II & 11 & 22,00 \\
\hline III & 39 & 78,00 \\
\hline Jumlah & $\mathbf{5 0}$ & $\mathbf{1 0 0 , 0 0}$ \\
\hline
\end{tabular}

Sumber: Data Penelitian, 2013

Dari tabel 3 di atas sesuai dengan tingkat pendidikannya bahwa mayoritas responden adalah golongan III, yaitu 39 orang atau 44,44\% dari jumlah sampel. Hal ini sesuai dengan mayoritas golongan pegawai pada Dinas Pendapatan, Pengelolaan Keuangan dan Aset (DPPKA) Kota Bengkulu adalah golongan III. 
d. Karakteristik responden berdasarkan usia.

Tabel 4. Karakteristik Responden Berdasarkan Usia

\begin{tabular}{|c|c|c|}
\hline Usia (tahun) & $\begin{array}{c}\text { Frekuensi } \\
\text { (orang) }\end{array}$ & Persentase (\%) \\
\hline $26-35$ & 25 & 50,00 \\
\hline $36-45$ & 4 & 8,00 \\
\hline $46-55$ & 21 & 42,00 \\
\hline Jumlah & $\mathbf{5 0}$ & $\mathbf{1 0 0 , 0 0}$ \\
\hline
\end{tabular}

Sumber: Data Penelitian, 2013

Tabel 4 di atas menunjukkan bahwa mayoritas responden berusia antara 26-35 tahun, yaitu 25 orang atau $50 \%$ dari jumlah sampel. Hal ini sesuai dengan tingkat pendidikan dan golongan responden, karena usia 26-35 adalah pegawai masih produktif dan pegawai yang masih baru dengan rata-rata pendidikan terendah adalah S1.

e. Karakteristik responden berdasarkan masa kerja

Tabel 5. Karakteristik Responden Berdasarkan Masa Kerja

\begin{tabular}{|c|c|c|}
\hline Masa Kerja (tahun) & $\begin{array}{c}\text { Frekuensi } \\
\text { (orang) }\end{array}$ & Persentase (\%) \\
\hline $0 \quad-10$ & 37 & 74,00 \\
\hline $10,1-20$ & 8 & 16,00 \\
\hline $20,1-30$ & 5 & 10,00 \\
\hline Jumlah & $\mathbf{5 0}$ & $\mathbf{1 0 0 , 0 0}$ \\
\hline
\end{tabular}

Sumber: Data Penelitian, 2013

Seperti yang telah dijelaskan sebelumnya bahwa dari segi pendidikan, golongan dan usia mayoritas responden berpendidikan S1, golongan III dan usia antara 26-35, dengan masa kerja responden mayoritas 0-10 tahun. Hal ini terlihat pada tabel 5 bahwa masa kerja responden mayoritas 0-10 tahun yaitu 37 atau $74 \%$ dari jumlah sampel.

\section{Persepsi Responden Terhadap Faktor-Faktor yang Mempengaruhi Kinerja Pegawai}

Dari hasil kuisioner yang disebarkan kepada 50 orang pegawai di lingkungan Dinas Pendapatan, Pengelolaan Keuangan dan Aset (DPPKA) Kota Bengkulu sebagai sampel dalam penelitian ini, diketahui persepsi responden terhadap faktor-faktor yang mempengaruhi kinerja pegawai, sebagai berikut:

a. Persepsi responden terhadap personal factors

Dari hasil kuisioner pada lampiran 2 tentang pernyataan yang berhubungan dengan personal factor, yaitu faktor dari dalam diri pegawai itu sendiri yang ditunjukkan oleh tingkat keterampilan, kompetensi yang dimiliki, motivasi dan komitmen yang dapat mempengaruhi kinerja pegawai. Berikut ini persepsi pegawai tentang personal factors seperti pada tabel 6 .

\section{Tabel 6. Persepsi Responden Terhadap Personal Factors}

\begin{tabular}{|c|c|c|c|c|c|c|c|c|}
\hline \multirow{2}{*}{ No } & \multirow{2}{*}{ Pernyataan } & \multicolumn{5}{|c|}{ Tanggapan Responden } & \multirow{2}{*}{ Jmlh } & \multirow{2}{*}{ Kriteria } \\
\hline & & SS & ST & RG & TS & STS & & \\
\hline 1. & $\begin{array}{l}\text { Kinerja yang baik didukung oleh keterampilan } \\
\text { pegawai yang bersangkutan }\end{array}$ & 18 & 26 & 3 & 1 & 2 & 207 & Setuju \\
\hline 2. & $\begin{array}{l}\text { Kinerja yang baik akan dipengaruhi oleh } \\
\text { kompetensi setiap pegawai }\end{array}$ & 13 & 28 & 2 & 4 & 3 & 194 & Setuju \\
\hline 3. & $\begin{array}{l}\text { Motivasi untuk maju setiap pegawai akan } \\
\text { mempengaruhi kinerj pegawai tersebut }\end{array}$ & 17 & 28 & 3 & 1 & 1 & 209 & Setuju \\
\hline 4. & $\begin{array}{l}\text { Komitmen pegawai terhadap organisasi akan } \\
\text { mempengaruhi kinerja pegawai }\end{array}$ & 15 & 29 & 1 & 3 & 2 & 202 & Setuju \\
\hline & Rata-Rata & & & & & & 203 & Setuju \\
\hline
\end{tabular}

Sumber: Data Penelitian, 2013 
Keterangan:

$50-90=$ Sangat Tidak Setuju

$91-130$ = Tidak Setuju

$131-170=$ Ragu-Ragu

$171-210=$ Setuju

$211-250=$ Sangat Setuju

Tabel 6 di atas menunjukkan persepsi 50 orang responden secara rata-rata menyatakan setuju bahwa kinerja pegawai pada Dinas Pendapatan, Pengelolaan Keuangan dan Aset (DPPKA) Kota Bengkulu dipengaruhi oleh personal factors.

Secara kontinum personal factors dapat digambarkan seperti pada gambar 2 .

\section{Gambar 2. Interval Jawaban Responden Terhadap Personal Factors}

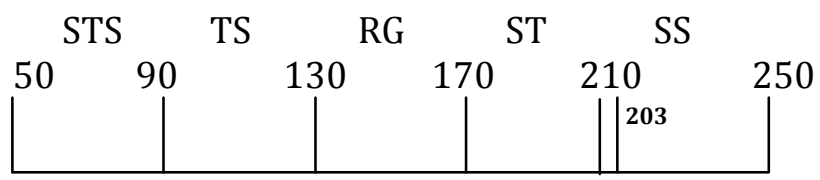

Sumber: Data Diolah, 2013

Dari gambar 2 di atas menunjukkan posisi nilai persepsi responden terhadap personal factors yang mempengaruhi kinerja pegawai Dinas Pendapatan, Pengelolaan Keuangan dan Aset (DPPKA) Kota Bengkulu dengan nilai rata-rata 203 berada pada interval 171-210 dengan kriteria setuju, walaupun ada beberapa responden yang menyatakan ragu-ragu, tidak setuju maupun sangat tidak setuju.

b. Persepsi responden terhadap leadership factors.

Dari hasil kuesioner pada lampiran 3 tentang pernyataan yang berhubungan dengan leadership factors, yaitu faktor yang mempengaruhi kinerja dengan ditentukan oleh kualitas dorongan, bimbingan, dan dukungan yang dilakukan manajer dan team leader. Hal ini menunjukkan besarnya peranan pimpinan dalam mengayomi bawahannya dalam melaksanakan tugas dan fungsi pokoknya dalam mencapai tujuan organisasi. Adapun persepsi responden terhadap leadership factors, seperti pada tabel 7.

Tabel 7. Persepsi Responden Terhadap Leadership Factors

\begin{tabular}{|c|c|c|c|c|c|c|c|c|}
\hline \multirow{2}{*}{ No } & \multirow{2}{*}{ Pernyataan } & \multicolumn{5}{|c|}{ Tanggapan Responden } & \multirow{2}{*}{ Jmlh } & \multirow{2}{*}{ Kriteria } \\
\hline & & SS & ST & $\mathbf{R G}$ & TS & STS & & \\
\hline 1. & 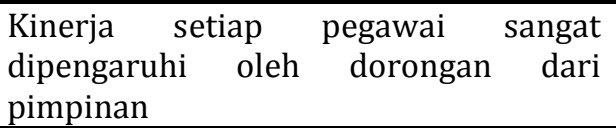 & 21 & 24 & 2 & 2 & 1 & 212 & $\begin{array}{l}\text { Sangat } \\
\text { Setuju }\end{array}$ \\
\hline 2. & $\begin{array}{l}\text { Agar kinerja setiap pegawai baik dan } \\
\text { tetap konsisten, tidak terlepas dari } \\
\text { bimbingan dari pimpinan }\end{array}$ & 19 & 25 & 3 & 2 & 1 & 209 & Setuju \\
\hline 3. & $\begin{array}{lcc}\text { Dukungan } & \text { pimpinan } & \text { akan } \\
\text { mempengaruhi kinerja setiap pegawai }\end{array}$ & 20 & 20 & 7 & 3 & - & 207 & Setuju \\
\hline 4. & $\begin{array}{l}\text { Petunjuk, arahan dan dukungan dari } \\
\text { pimpinan sangat dibutuhkan agar hasil } \\
\text { kerja sesuai dengan yang diharapkan }\end{array}$ & 23 & 25 & 2 & - & - & 221 & $\begin{array}{l}\text { Sangat } \\
\text { Setuju }\end{array}$ \\
\hline & Rata-Rata & & & & & & 212,25 & $\begin{array}{l}\text { Sangat } \\
\text { Setuju }\end{array}$ \\
\hline
\end{tabular}

Sumber: Data Penelitian 2013

Keterangan:

$50-90=$ Sangat Tidak Setuju

$91-130=$ Tidak Setuju

$131-170=$ Ragu-Ragu

$171-210=$ Setuju

$211-250=$ Sangat Setuju 
Tabel 7 di atas menunjukkan persepsi 50 orang responden secara rata-rata menyatakan sangat setuju bahwa kinerja pada Dinas Pendapatan, Pengelolaan Keuangan dan Aset (DPPKA) Kota Bengkulu pada saat ini dipengaruhi oleh leadership factors.

Secara kontinum leadership factors dapat digambarkan seperti pada gambar 3.

\section{Gambar 3. Interval Jawaban Responden Leadership Factors}

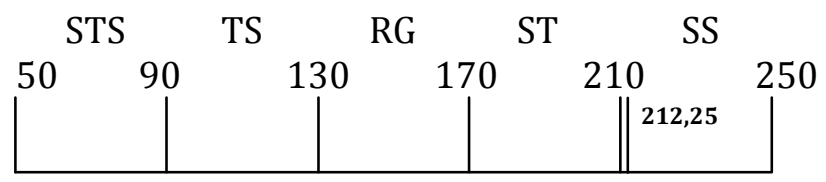

Sumber: Data Diolah, 2013

Dari gambar 3 di atas menunjukkan nilai rata-rata persepsi responden 212,25 atau berada pada interval 211-250 dengan kriteria sangat setuju, walaupun ada beberapa pernyataan dijawab ragu-ragu, tidak setuju dan sangat tidak setuju.

c. Persepsi responden terhadap team factors.

Dari hasil kuesioner pada lampiran 4 tentang pernyataan yang berhubungan dengan team factors, yang ditunjukkan oleh kualitas dukungan rekan sekerja, karena dukungan rekan sekerja sangat diperlukan dalam melaksanakan tugas dan fungsi pokoknya. Adapun persepsi responden terhadap team factors seperti pada tabel 8.

\section{Tabel 8. Persepsi Responden Terhadap Team Factors}

\begin{tabular}{|c|c|c|c|c|c|c|c|c|}
\hline \multirow{2}{*}{ No } & \multirow{2}{*}{ Pernyataan } & \multicolumn{5}{|c|}{ Tanggapan Responden } & \multirow{2}{*}{ Jmlh } & \multirow{2}{*}{ Kriteria } \\
\hline & & SS & ST & RG & TS & STS & & \\
\hline 1. & $\begin{array}{l}\text { Kinerja pegawai juga dipengaruhi oleh rekan } \\
\text { sekerja }\end{array}$ & 14 & 19 & 7 & 8 & 2 & 185 & Setuju \\
\hline 2. & $\begin{array}{l}\text { Kerja sama dan hubungan baik dengan rekan } \\
\text { sekerja akan mempengaruhi kinerja pegawai }\end{array}$ & 13 & 25 & 7 & 4 & 1 & 195 & Setuju \\
\hline 3. & $\begin{array}{lcccr}\text { Pelaksanaan tugas dan fungsi dapat } & \text { dan } \\
\text { dilaksanakan dengan baik, jika mendapat } \\
\text { dukungan rekan sekerja }\end{array}$ & 13 & 27 & 10 & - & - & 203 & Setuju \\
\hline 4. & $\begin{array}{l}\text { Saran, petunjuk yang baik dalam melaksanakan } \\
\text { tugas dari rekan sekerja akan menghasilkan } \\
\text { kinerja yang baik }\end{array}$ & 5 & 31 & 14 & - & - & 191 & Setuju \\
\hline
\end{tabular}

Sumber: Data Penelitian, 2013

Keterangan:

$50-90=$ Sangat Tidak Setuju

$91-130=$ Tidak Setuju

$131-170=$ Ragu-Ragu

$171-210=$ Setuju

$211-250=$ Sangat Setuju

Dari tabel 8 di atas menunjukkan bahwa team factors juga merupakan faktor yang mempengaruhi kinerja pegawai Dinas Pendapatan, Pengelolaan Keuangan dan Aset (DPPKA) Kota Bengkulu.

Secara kontinum team factors dapat digambarkan seperti pada gambar 4.

Gambar 4. Interval Jawaban Responden Terhadap Team Factors

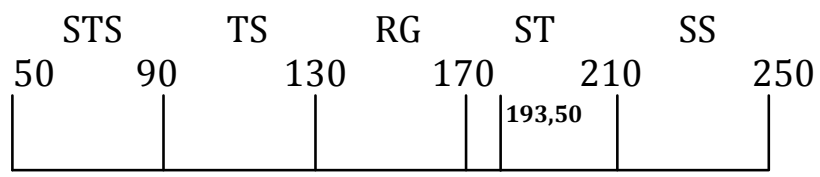

Sumber: Data Diolah, 2013 
Dari gambar 4 di atas menunjukkan bahwa responden setuju bahwa team factors mempengaruhi kinerja pegawai, yang ditunjukkan nilai rata-rata persepsi responden sebesar 193,50 berada pada interval 171-210 dengan kriteria setuju, walaupun ada beberapa responden yang menyatakan ragu-ragu, tidak setuju, dan sangat tidak setuju.

d. Persepsi responden terhadap system factors.

Dari hasil kuesioner pada lampiran 5 tentang pernyataan yang berhubungan dengan system factor yang ditunjukkan oleh adanya sistem kerja dan fasilitas yang diberikan organisasi yang dapat memotivasi pegawai dalam meningkatkan kinerjanya. Adapun persepsi responden terhadap system factors seperti pada tabel 9.

\section{Tabel 9. Persepsi Responden Terhadap System Factors}

\begin{tabular}{|c|l|c|c|c|c|c|c|l|}
\hline \multicolumn{1}{|c}{ Pernyataan } & \multicolumn{3}{c}{ Tanggapan Responden } & \multicolumn{2}{c|}{ Jmlh } & \multicolumn{2}{c|}{ Kriteria } \\
\hline 1. & $\begin{array}{l}\text { Kinerja setiap pegawai tidak terlepas dari } \\
\text { sistem yang ada dalam organisasi }\end{array}$ & 17 & 27 & 3 & 2 & 1 & 207 & Setuju \\
\hline 2. & $\begin{array}{l}\text { Kinerja pegawai akan dipengaruhi oleh fasilitas } \\
\text { yang ada dalam organisasi }\end{array}$ & 16 & 26 & 5 & 3 & - & 205 & Setuju \\
\hline 3. & $\begin{array}{l}\text { Adanya sistem perencanaan karier yang baik } \\
\text { akan memberi motivasi setiap pegawai untuk } \\
\text { meningkatkan kinerjanya }\end{array}$ & 19 & 26 & 4 & - & 1 & 212 & $\begin{array}{l}\text { Sangat } \\
\text { Setuju }\end{array}$ \\
\hline 4. & $\begin{array}{l}\text { Adanya dukungan teknologi informasi yang } \\
\text { memadai akan mendukung pelaksanaan tugas } \\
\text { dan fungsi yang cepat dan tepat }\end{array}$ & 13 & 29 & 8 & - & - & 205 & Setuju \\
\hline
\end{tabular}

Sumber: Data Penelitian, 2013

Keterangan:

$50-90=$ Sangat Tidak Setuju

$91-130=$ Tidak Setuju

$131-170$ = Ragu-Ragu

$171-210=$ Setuju

$211-250=$ Sangat Setuju

Dari tabel 9 di atas diperoleh nilai rata-rata persepsi responden yang menunjukkan bahwa responden setuju bahwa system factors ikut mempengaruhi kinerja pegawai Dinas Pendapatan, Pengelolaan Keuangan dan Aset (DPPKA) Kota Bengkulu.

Secara kontinum system factors dapat digambarkan seperti pada gambar 5.

\section{Gambar 5. Interval Jawaban Responden Terhadap System Factors}

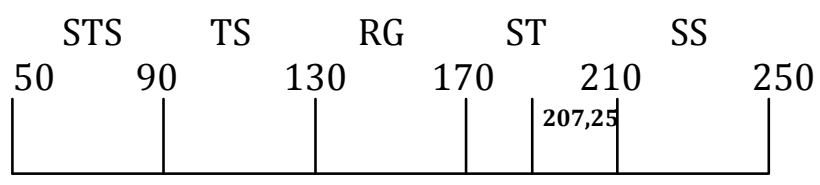

Sumber: Data Diolah, 2013

Dari gambar 5 di atas bahwa persepsi responden terhadap system factors sebesar 207,25 berada pada interval 171-210 dengan kriteria setuju, walaupun ada beberapa pernyataan mendapat persepsi dari responden ragu-ragu, tidak setuju dan sangat tidak setuju.

e. Persepsi responden terhadap contextual factors.

Dari hasil kuesioner pada lampiran 6 tentang pernyataan yang berhubungan contextual factors yang ditunjukkan tingginya tingkat tekanan dan perubahan lingkungan internal dan eksternal. Adapun persepsi responden terhadap contextual factors seperti pada tabel 10 . 
Tabel 10.Persepsi Responden Terhadap Contextual Factors

\begin{tabular}{|c|l|l|l|l|l|l|l|l|}
\hline No & \multicolumn{9}{c}{ Pernyataan } & \multicolumn{1}{c}{ Tanggapan Responden } & \multicolumn{2}{c|}{ Jmlh } & \multicolumn{2}{c|}{ Kriteria } \\
\hline 1. & $\begin{array}{l}\text { Tekanan dari pimpinan akan membuat pegawai } \\
\text { menjadi stress dan mempengaruhi kinerja }\end{array}$ & 21 & 10 & 2 & 10 & 7 & 178 & Setuju \\
\hline 2. & $\begin{array}{l}\text { Suasana organisasi yang tidak nyaman } \\
\text { membuat pegawai menjadi malas yang akan } \\
\text { berpengaruh pada kinerja pegawai }\end{array}$ & 15 & 16 & 5 & 7 & 7 & 175 & Setuju \\
\hline 3. & $\begin{array}{l}\text { Dukungan dari lingkungan eksternal khususnya } \\
\text { lingkungan terdekat dengan instansi akan } \\
\text { mempengaruhikinerja pegawai }\end{array}$ & 15 & 22 & 13 & - & - & 152 & Setuju \\
\hline 4. & $\begin{array}{l}\text { Perubahan lingkungan organisasi juga akan } \\
\text { mempengaruhi kinerja pegawai }\end{array}$ & 14 & 17 & 4 & 9 & 6 & 174 & Setuju \\
\hline
\end{tabular}

Sumber: Data Penelitian, 2013

Keterangan:

$50-90=$ Sangat Tidak Setuju

$91-130=$ Tidak Setuju

$131-170=$ Ragu-Ragu

$171-210=$ Setuju

$211-250=$ Sangat Setuju

Dari tabel 10 di atas menunjukkan bahwa responden setuju bahwa contextual factors juga mempengaruhi kinerja pegawai Dinas Pendapatan, Pengelolaan Keuangan dan Aset (DPPKA) Kota Bengkulu.

Secara kontinum contextual factors dapat digambarkan seperti pada gambar 6.

Gambar 6. Interval Jawaban Responden Terhadap Contextual Factors

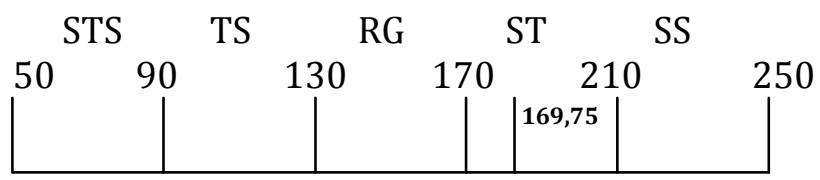

Sumber: Data Diolah, 2013

Dari gambar 6 di atas menunjukkan bahwa persepsi responden terhadap contextual factors dengan nilai rata-rata 183,5 berada pada interval 171-210 dengan kriteria setuju, ini menunjukkan bahwa responden setuju bahwa adanya tekanan baik dari pihak intern maupun ekstern berpengaruh pada kinerja pegawai pada Dinas Pendapatan, Pengelolaan Keuangan dan Aset (DPPKA) Kota Bengkulu.

\section{PEMBAHASAN}

Faktor-Faktor yang Mempengaruhi Kinerja Pegawai Dinas Pendapatan, Pengelolaan Keuangan dan Aset (DPPKA) Kota Bengkulu

Dari hasil penelitian dalam bentuk hasil kuisioner diperoleh persepsi responden tentang faktor-faktor yang mempengaruhi kinerja Pegawai Negeri Sipil di lingkungan Dinas Pendapatan, Pengelolaan Keuangan dan Aset (DPPKA) Kota Bengkulu dengan variabel penelitian terdiri dari personal factors, leadership factors, team factors, system factors, dan contextual factors.

Dari kelima faktor tersebut, empat faktor memperoleh persepsi dari responden dengan kriteria setuju, artinya responden setuju bahwa keempat faktor tersebut mempengaruhi kinerja pegawai pada Dinas Pendapatan, Pengelolaan Keuangan dan Aset (DPPKA) Kota Bengkulu. Sedangkan satu faktor yaitu leadership factors mendapat persepsi dari responden sangat setuju, hal ini menunjukkan bahwa peran pimpinan sangat besar dalam memotivasi dan meningkatkan kinerja pegawai. 
Secara rinci persepsi responden terhadap lima faktor-faktor yang mempengaruhi kinerja pegawai Dinas Pendapatan, Pengelolaan Keuangan dan Aset (DPPKA) Kota Bengkulu, sebagai berikut:

\section{a. Personal factors}

Hasil penelitian pada tabel 6 diperoleh nilai rata-rata persepsi responden terhadap variabel personal factors sebesar 203 berada pada interval 171-210 dengan kriteria setuju. Nilai ini menunjukkan bahwa kinerja yang baik akan dipengaruhi oleh diri pegawai itu sendiri, rasa tanggung jawab terhadap tugas yang diemban, motivasi untuk maju dalam berkarier akan mendorong pegawai tersebut untuk melaksanakan tugas dengan sebaikbaiknya.

Ditinjau dari personal factors, kinerja pegawai Dinas Pendapatan, Pengelolaan Keuangan dan Aset (DPPKA) Kota Bengkulu ditentukan oleh keterampilan, kompetensi yang dimiliki, motivasi dan komitmen individu. Hal ini menunjukkan bahwa untuk menghasilkan kinerja yang baik, seorang pegawai harus mempunyai kemampuan yang ditunjukkan oleh keterampilan dan kompetensi pegawai, sesuai dengan kebutuhan saat ini bahwa Pegawai Negeri Sipil minimal harus berpendidikan Diploma dan S1.

Personal factor juga tidak terlepas dari perilaku dari pegawai yang bersangkutan, seperti yang dijelaskan oleh Kottze dalam Wibowo (2011:86), bahwa faktor yang mendorong kinerja adalah perilaku. Perilaku adalah tentang bagaimana anda bertindak (how you act), dan bukan tentang apa atau siapa anda (what you are or who you are). Perilaku adalah suatu cara di mana seseorang bertindak atau melakukan. Karena dapat menentukan apa yang akan dilakukan dalam setiap situasi, anda dapat menentukan kinerja anda.

b. Leadership factors.

Hasil penelitian tentang persepsi responden terhadap leadership factor pada tabel 7 diketahui bahwa pimpinan merupakan salah satu faktor yang sangat mempengaruhi pegawai pada Dinas Pendapatan, Pengelolaan Keuangan dan Aset (DPPKA) Kota Bengkulu. Leadership adalah tentang mengupayakan orang dalam hal ini pegawai dari atas sampai ke bawah dalam organisasi memperbaiki kinerjanya. Hal ini sejalan dengan penjelasan Wibowo (2011:105), bahwa suatu organisasi mencapai sukses untuk sebagian besar ditentukan oleh manajer. Apabila manajer melakukan pekerjaan dengan baik, organisasi mungkin mencapai tujuannya. Namun, apabila sebaliknya manajer tidak mampu melakukan tugasnya, organisasi akan gagal mencapai tujuan.

Penjelasan di atas menguatkan persepsi responden yang menyatakan sangat setuju bahwa leadership factors sangat mempengaruhi kinerja pegawai pada Dinas Pendapatan, Pengelolaan Keuangan dan Aset (DPPKA) Kota Bengkulu.

c. Team factors.

Dalam menjalankan tugas dan fungsi pokoknya setiap pegawai tidak terlepas dari pegawai dilingkungannya, artinya kerja sama tim sangat dibutuhkan untuk menghasilkan kinerja dengan baik. Hasil penelitian tentang persepsi responden terhadap team factors seperti pada tabel 8, mendapat persepsi dari responden dengan kriteria setuju. Hal ini sejalan dengan pendapat Wibowo (2011:107), bahwa seseorang apabila bekerja untuk dirinya sendiri, prestasinya dapat berbeda dengan apabila bekerja bersama orang lain dalam kelompok. Kinerjanya dapat menjadi lebih baik dan meningkat, namun sering kali menjadi merosot apabila salah dalam menanganinya.

d. System factors.

Hasil penelitian tentang persepsi responden terhadap system factors seperti pada tabel 9 mendapat persepsi dari responden dengan kriteria setuju. Ini menujukkan bahwa sistem yang dibentuk pada Dinas Pendapatan, Pengelolaan Keuangan dan Aset (DPPKA) Kota Bengkulu akan mempengaruhi kinerja pegawai, karena sistem yang tidak baik khususnya sistem jenjang karier akan membuat pegawai menjadi malas dan tidak disiplin sehingga kinerja pegawai menjadi jelek.

e. Contextual factors

Hasil penelitian pada tabel 10 tentang persepsi responden terhadap contextual factor diperoleh nilai rata-rata dengan kriteria setuju artinya pegawai Dinas Pendapatan, 
Pengelolaan Keuangan dan Aset (DPPKA) Kota Bengkulu, merasakan bahwa adanya tekanan baik dari dalam maupun dari luar instansi akan mempengaruhi kinerja pegawai.

Melaksanakan tugas dan fungsi pokok deangan baik tanpa ada beban dan tekanan dari atasan atau rekan sekerja akan menghasilkan kinerja yang baik, sebaliknya bekerja dengan penuh beban tidak akan dapat menyelesaikan pekerjaan dengan baik, artinya kinerja pegawai tersebut tidak baik.

Faktor yang Paling Dominan Mempengaruhi Kinerja Pegawai pada Dinas Pendapatan, Pengelolaan Keuangan dan Aset (DPPKA) Kota Bengkulu

Dari hasil penelitian dan pembahasan tentang faktor-faktor yang mempengaruhi kinerja pegawai pada Dinas Pendapatan, Pengelolaan Keuangan dan Aset (DPPKA) Kota Bengkulu. Adapun faktor-faktor yang menjadi fokus dalam penelitian dan nilai yang diperoleh dari persepsi responden dikumpul lewat kuisioner dan diolah seperti pada tabel 6-10. Untuk menentukan faktor yang paling dominan mempengaruhi pengembangan karier akan diurut seperti pada tabel 11 .

Tabel 11. Nilai Rata-Rata Setiap Variabel Penelitian

\begin{tabular}{|l|c|c|}
\multicolumn{1}{|c|}{ Variabel Penelitian } & $\begin{array}{c}\text { Jumlah Skor } \\
\text { Rata-Rata }\end{array}$ & Kriteria \\
\hline Personal Factors & 203,00 & Setuju \\
\hline Leadership Factors & 212,25 & Sangat Setuju \\
\hline Team Factors & 193,50 & Setuju \\
\hline System Factors & 207,25 & Setuju \\
\hline Contextual Factors & 169,75 & Setuju \\
\hline Jumlah Skor & $\mathbf{9 8 5 , 7 5}$ & \\
Rata-Rata & $\mathbf{1 9 7 , 1 5}$ & Setuju \\
\hline
\end{tabular}

Sumber: Tabel 6-10 Diolah, 2013

Keterangan:

$50-90=$ Sangat Tidak Setuju

$91-130=$ Tidak Setuju

$131-170=$ Ragu-Ragu

$171-210=$ Setuju

$211-250=\quad$ Sangat Setuju

Dari tabel $11 \mathrm{di}$ atas diketahui bahwa faktor yang paling dominan mempengaruhi kinerja pegawai pada Dinas Pendapatan, Pengelolaan Keuangan dan Aset (DPPKA) Kota Bengkulu adalah leadership factors dengan jumlah nilai rata-rata dari persepsi responden 212,25 dengan kriteria sangat setuju. Untuk lebih jelas akan diurut dengan menggunakan rating scale, seperti pada tabel 12 di bawah ini:

Tabel 12. Perengkingan Faktor-Faktor yang Mempengaruhi Kinerja

\begin{tabular}{|c|l|}
$\begin{array}{c}\text { Nomor } \\
\text { Rangking }\end{array}$ & \multicolumn{1}{c|}{ Faktor-Faktor yang Mempengaruhi Kinerja } \\
\hline I & 1. Leadership factors \\
II & 2. Personal factors \\
III & 3. Team factors \\
IV & 4. System factors \\
V & 5. Countextual Factors \\
\hline
\end{tabular}

Sumber: Tabel 11, Diolah 2013

Dari Tabel 12 di atas menunjukkan bahwa leadership factors atau faktor pemimpin sangat mempengaruhi kinerja pegawai pada Dinas Pendapatan, Pengelolaan Keuangan dan Aset (DPPKA) Kota Bengkulu, ini menunjukkan betapa pentingnya peran seorang pemimpin dalam mengayomi bawahannya agar dapat menjalankan aktivitasnya sesuai dengan tanggung jawab, tugas dan fungsinya setiap pegawai dengan baik. Selain itu faktor dari pegawai itu sendiri 
(personal factors) juga ikut mempengaruhi kinerjanya, karena walaupun memiliki pimpinan yang baik jika tidak ada kompetensi, keterampilan dan motivasi dari pegawai itu sendiri juga tidak menghasilkan kinerja yang baik. Contextual Factors, juga mempengaruhi dalam pencapaian kinerja pegawai Dinas Pendapatan, Pengelolaan Keuangan dan Aset (DPPKA) Kota Bengkulu dalam melaksanakan tugas pokok dan fungsi dengan baik tanpa adanya beban dan tekanan dari atasan atau rekan sekerja dan lingkungan organisasi maka akan menghasilkan kinerja yang baik, sebaliknya bekerja dengan penuh beban, tekan dan lingkungan organisasi yang tidak mendukung maka tidak akan dapat menyelesaikan pekerjaan dengan baik.

Sistem yang dibentuk pada Dinas Pendapatan, Pengelolaan Keuangan dan Aset (DPPKA) Kota Bengkulu, juga harus diperhatikan karena sistem yang jelek khususnya dalam jenjang karir akan membuat pegawai tidak akan termotivasi untuk menjalankan aktivitasnya dengan baik. Begitu juga dengan kerjasama tim dan dukungan baik dari internal maupun eksternal.

Sedangkan faktor yang paling kecil memperoleh skor persepsi dari responden adalah countextual factors tetapi masih dalam kategori setuju, artinya ingkat tekanan dan perubahan lingkungan internal dan ekstenal mempengaruhi kinerja pegawai pada Dinas Pendapatan, Pengelolaan Keuangan dan Aset (DPPKA) Kota Bengkulu. Selain itu persepsi responden terhadap faktor ini menunjukkan bahwa tingkat tekanan dan perubahan lingkungan internal dan eksternal yang terdiri dari tekanan dari pimpinan, suasana organisasi, dukungan dari luar, dan perubahan lingkungan organisasi sudah menunjukkan ke arah yang baik sehingga akan mempengaruhi kinerja pegawai karena skor dari responden berada pada kriteria setuju.

Dari hasil pembahasan di atas menunjukkan bahwa ke lima faktor yang menjadi fokus penelitian ini mendapat persepsi dari responden dengan nilai rata-rata 197,15 dengan kriteria setuju, artinya ke lima faktor yang mempengaruhi kinerja, yaitu personal factors, leadership factors, team factors, system factors dan countextual factors mempengaruhi kinerja pegawai pada Dinas Pendapatan, Pengelolaan Keuangan dan Aset (DPPKA) Kota Bengkulu.

\section{Kesimpulan}

berikut:

Dari hasil penelitian dan pembahasan dapat ditarik beberapa kesimpulan, sebagai

1. Dari lima faktor yang mempengaruhi kinerja pegawai pada Dinas Pendapatan, Pengelolaan Keuangan dan Aset (DPPKA) Kota Bengkulu, empat faktor yaitu personal factos, team factors, system factor, dan contextual factors mendapat persepsi dari responden dengan kriteria setuju, artinya keempat faktor tersebut mempengaruhi kinerja pegawai. Sedangkan satu faktor yaitu leadership factors mendapat persepsi sangat setuju, artinya pemimpin sangat mempengaruhi kinerja pegawai.

2. Faktor yang paling dominan mempengaruhi kinerja pegawai pada Dinas Pendapatan, Pengelolaan Keuangan dan Aset (DPPKA) Kota Bengkulu adalah leadership factors, karena mempunyai peranan penting dalam mengayomi, mendukung dan memotivasi kerja pegawai.

3. Dari empat pernyataan tentang leadership factors pernyataan keempat mendapat nilai paling tinggi dengan kriteria sangat setuju, yaitu petunjuk arahan dan dukungan pimpinan sangat dibutuhkan agar hasil kerja sesuai dengan yang diharapkan.

4. Personal factors, faktor yang dominan kedua menurut responden karena kinerja juga ditentukan oleh pegawai itu sendiri.

\section{Saran}

1. Hasil penelitian menunjukkan bahwa leadership factors adalah faktor yang paling dominan mempengaruhi kinerja pegawai, untuk itu disarankan kepada pemimpin dalam hal ini Kepala Dinas, Kepala Bagian/Kepala Bidang, dan Kepala Seksi agar menjadi teladan, contoh, dan dukungan kepada bawahannya dalam menjalankan aktivitasnya.

2. Secara umum kelima faktor yang mempengaruhi kinerja pegawai pada Dinas Pendapatan, Pengelolaan Keuangan dan Aset (DPPKA) Kota Bengkulu mendapat persepsi setuju dari responden untuk itu disarankan kepada pimpinan untuk memperhatikan faktor-faktor 
tersebut, karena pada intinya keempat faktor tersebut dapat tumbuh dan dibangun melalui kepemimpinan seorang pemimpin.

\section{DAFTAR PUSTAKA}

Amri. 2011. Hubungan Pendidikan dan Pelatihan (Diklat) Dengan Kinerja Pegawai Badan Pendidikan dan Pelatihan Provinsi Bengkulu. Skripsi. Universitas Dehasen. Bengkulu.

As'ad, Muhammad. 2002. Psikologi Industri. Liberti. Yogyakarta.

Dessler, Gary. 2010.Manajemen Sumber Daya Manusia. Indeks. Jakarta.

Fathoni, Abdurrahmat. 2006. Manajemen Sumber Daya Manusia. Rineka Cipta. Jakarta.

Fuad, Hasan. 2000. Manajemen Sekolah. Depdiknas. Jakarta.

Gomes, Faustino Cardoso. 2009. Manajemen Sumber Daya Manusia. Andi. Yogyakarta.

Handoko, T. Hani. 2008. Manajemen. BPFE. Yogyakarta.

Hasibuan, S.P Melayu. 2001. Organisasi dan Motivasi Dasar Peningkatan Produktivitas. Bumi Aksara. Jakarta.

Hasibuan, S.P. Malayu. 2008. Manajemen Dasar, Pengertian dan Masalah. PT. Toko Gunung Agung. Jakarta.

Kuzasih, Henni. 2012. Hubungan Komitmen Organisai Dengan Kinerja Pegawai pada Biro Pengelolaan Keuangan Sekretariat Daerah Provinsi Bengkulu. Skripsi. Univesitas Dehasen. Bengkulu.

Mangkunegara, Prabu Anwar. 2006. Manajemen Sumber Daya Manusia. Tri Genda Karya. Bandung.

Ratminto dan Atik Septi Winarsih. 2007. Manajemen Pelayanan. Pustaka Pelajar. Yogyakarta.

Rivai, Veithzal dan Deddy Mulyadi. 2004. Kepemimpinan dan Perilaku Organisasi. PT. RajaGrafindo Persada. Jakarta.

Sari. W, Irine Diana. 2011. Metode Pemasaran Rumah Sakit. Nuha Medika. Yogyakarta.

Schuller, Sherman Randal dan Hubber. 2003. People Related Business. Erlangga. Jakarta.

Sedarmayanti. 2005. Manajemen Sumber Daya Manusia dan Produktivitas Kerja. Mandar Maju. Bandung.

Sugiyono. 2009. Metode Penetian Bisnis. Alfabeta. Bandung.

Sutrisno, Edy. 2011. Manajemen Sumber Daya Manusia. Kencana Prenada Media Group. Jakarta.

Triton. PB. 2010. Manajemen Sumber Daya Manusia Perspektif Partnership dan Kolektivitas. PT. Suka Buku. Jakarta.

Terry, George R dan Leslie W. Rue. 2005. Dasar-Dasar Manajemen. Bumi Aksara. Jakarta. 
Analisis Faktor-faktor yang Mempengaruhi Kinerja Pegawai pada Dinas Pendapatan, Pengelolaan Keuangan dan Aset (DPPKA) Kota Bengkulu

Tyson dan Jackson. 2001. Seri Manajemen Sumber Daya Manusia. Gramedia. Jakarta.

Umar, Husein. 2005. Riset Sumber Daya Manusia Dalam Organisasi. PT. Gramedia Pustaka Utama. Jakarta.

Wibowo. 2011. Manajemen Kinerja. PT. Raja Grafindo Persada. Jakarta. 